\title{
Methionine and choline supply alter transmethylation, transsulfuration, and cytidine 5'-diphosphocholine pathways to different extents in isolated primary liver cells from dairy cows
}

\author{
Y. F. Zhou, ${ }^{\star} †$ Z. Zhou,‡ F. Batistel,† I. Martinez-Cortés,§ R. T. Pate,† D. L. Luchini,\# and J. J. Loor† ${ }^{1}$ \\ *Department of Animal Nutrition and Feed Science, College of Animal Science and Technology, Huazhong Agriculture University, Wuhan 430070 , \\ Hubei, China \\ †Mammalian NutriPhysioGenomics, Department of Animal Sciences and Division of Nutritional Sciences, University of Illinois, Urbana 61801 \\ fDepartment of Animal and Veterinary Sciences, Clemson University, Clemson 29634 \\ $\S$ Department of Immunology, National Autonomous University of Mexico (UNAM), Mexico City, Mexico 04510 \\ \#Adisseo NA, Alpharetta, GA 30022
}

\begin{abstract}
Insufficient supply of Met and choline (Chol) around parturition could compromise hepatic metabolism and milk protein synthesis in dairy cows. Mechanistic responses associated with supply of Met or Chol in primary liver cells enriched with hepatocytes (PHEP) from cows have not been thoroughly ascertained. Objectives were to isolate and culture PHEP to examine abundance of genes and proteins related to transmethylation, transsulfuration, and cytidine 5'-diphosphocholine (CDP-choline) pathways in response to Met or Chol. The PHEP were isolated from liver biopsies of Holstein cows (160 d in lactation). More than $90 \%$ of isolated cells stained positively for the hepatocyte marker cytokeratin 18. Cytochrome P450 (CYP1A1) mRNA abundance was only detectable in the PHEP and liver tissue compared with mammary tissue. Furthermore, in response to exogenous Met $(80 \mu M$ vs. control) PHEP secreted greater amounts of albumin and urea. Subsequently, PHEP were cultured with Met $(40 \mu M)$ or Chol $(80 \mathrm{mg} / \mathrm{dL})$ for $24 \mathrm{~h}$. Compared with control or Chol, mRNA and protein abundance of methionine adenosyltransferase $1 \mathrm{~A}(M A T 1 A)$ and phosphatidylethanolamine methyltransferase $(P E M T)$ were greater in PHEP treated with Met. The mRNA abundance of S-adenosylhomocysteine hydrolase $(S A H H)$, betaine-homocysteine methyltransferase (BHMT), and sarcosine dehydrogenase $(S A R D H)$ was greater in Met-treated PHEP compared with control or Chol. Compared with control, greater expression of 5-methyltetrahydrofolate-homocysteine methyltransferase $(M T R)$, betaine aldehyde dehydrogenase $(B A D H)$, and choline dehydrogenase $(\mathrm{CHDH})$ was observed in cells
\end{abstract}

Received December 2, 2017.

Accepted September 7, 2018.

${ }^{1}$ Corresponding author: jloor@illinois.edu supplemented with Met and Chol. However, Chol led to the greatest mRNA abundance of $C H D H$. Abundance of choline kinase $\alpha(C H K A)$, choline kinase $\beta(C H K B)$, phosphate cytidylyltransferase $1 \propto$ (PCYT1A), and choline/ethanolamine phosphotransferase 1 (CEPT1) in the CDP-choline pathway was greater in PHEP treated with Chol compared with control or Met. In the transsulfuration pathway, mRNA and protein abundance of cystathionine $\beta$-synthase (CBS) was greater in PHEP treated with Met compared with control or Chol. Similarly, abundance of cysteine sulfinic acid decarboxylase $(C S A D)$, glutamate-cysteine ligase, catalytic subunit $(G C L C)$, and glutathione reductase $(G S R)$ was greater in response to Met compared with control or Chol. Overall, these findings suggest that transmethylation and transsulfuration in dairy cow primary liver cells are more responsive to Met supply, whereas the CDPcholine pathway is more responsive to Chol supply. The relevance of these data in vivo merit further study.

Key words: 1-carbon metabolism, methyl donors, lactation

\section{INTRODUCTION}

In addition to their essential role as nutrients, Met and choline (Chol; 2 key molecules in the 1-carbon metabolism pathway) contribute to metabolic regulation through transmethylation, transsulfuration, and the cytidine 5'-diphosphocholine (CDP-choline) pathways (Ducker and Rabinowitz, 2017). The initial step in transmethylation involves the conversion of Met to S-adenosylmethionine (SAM), the principal donor of methyl groups, followed by metabolism to homocysteine via the S-adenosyl homocysteine intermediate (Tavares et al., 2016). Homocysteine can then either be recycled back to Met in a folate/Chol-dependent manner or can be rapidly converted to cystathionine and then to taurine and glutathione (the major intracellular 
antioxidants) via the transsulfuration pathway (Kalhan and Marczewski, 2012; Tavares et al., 2016; Zhou et al., 2017). Data indicate that methyl group transfer in ruminant and nonruminant species is closely related to the metabolism of Met and Chol (Corbin and Zeisel, 2012).

The liver is the main organ where the 1-carbon and Met metabolism pathways overlap (Speckmann et al., 2017), with phosphatidylcholine (PC) synthesis being the largest 1-carbon sink in the liver and necessary for the packaging and export of triacylglycerol into very low density lipoproteins (VLDL; Corbin and Zeisel, 2012). Nonruminant research has demonstrated conclusively that methyl donor deficiency impairs liver function and causes inflammation due to an augmentation in oxidative stress (Pooya et al., 2012). At least in rodents, a deficiency in Met and Chol can induce hepatic steatosis, oxidative stress, and inflammation (Jha et al., 2014).

Dietary Met and Chol supplementation around parturition in rumen-protected form increased milk yield and milk protein concentration (Sales et al., 2010; Osorio et al., 2013; Zhou et al., 2016c), and Met improved immunometabolic status in dairy cows during the peripartal period (Osorio et al., 2014b; Zhou et al., 2016a). Furthermore, compared with Chol, greater supply of Met resulted in increased antioxidant concentration in liver tissue in spite of lower concentration of PC (Zhou et al., 2017). Those responses were due to the greater abundance of phosphatidylethanolamine methyltransferase (PEMT) and cystathionine $\beta$-synthase (CBS; Zhou et al., 2017). A greater supply of Chol did not change the mRNA abundance of betaine-homocysteine methyltransferase (BHMT) and 5-methyltetrahydrofolate- homocysteine methyltransferase (MTR) in cows with a greater supply of Chol.

Physiologic changes during the transition period often lead to health disorders, and a growing body of data underscores that regulation of those processes occurs at the molecular (mRNA, protein) and enzymatic level (Loor et al., 2013). Lipid accumulation in liver may contribute to health disorders and decreased milk production (Roche et al., 2013). The regulation and coordination of lipid metabolism (at molecular, enzyme, and metabolite level) among adipose tissue, liver, gut, and mammary gland are key components of the adaptations to lactation (Loor et al., 2013). Although several recent studies have enhanced the mechanistic understanding of the role of Met and Chol in the context of the physiology of the periparturient cow (Zhou et al., 2016a,b, 2017; Zenobi et al., 2018), studying mechanistic aspects of Met and Chol metabolism in liver in vivo becomes challenging.

As is routine in research with nonruminant species, isolation and culture of primary liver cells enriched with hepatocytes (PHEP) may provide an efficient system for in vitro studies. Although recent studies using neonatal calf hepatocytes indicated that supply of Met decreased the mRNA expression of BHMT, MTR, and 5,10 methylenetetrahydrofolate reductase (Zhang et al., 2016), and that Chol and Met have distinct effects on the 1-carbon metabolism pathway (Chandler and White, 2017), PHEP from neonatal dairy calves are functionally and transcriptionally distinct compared with adult dairy cows (Batistel et al., 2016).

We hypothesized that Met and Chol induce distinct changes in 1-carbon metabolism by altering mRNA and protein abundance of key genes in the transmethylation, transsulfuration, and CDP-choline pathways in PHEP from dairy cows. The objectives of the present study were to isolate, characterize, and culture PHEP from dairy cows to measure the abundance of key genes and proteins in the transmethylation, transsulfuration, and CDP-choline pathways in response to Met and Chol supplementation.

\section{MATERIALS AND METHODS}

\section{Isolation and Culture of Dairy Cow PHEP}

All animal procedures for this study (protocol no. 13023) were approved by the Institutional Animal Care and Use Committee of the University of Illinois. A nonperfusion technique (Lemley and Wilson, 2010) was used with liver tissue (1-3 g) harvested via puncture biopsy (Zhou et al., 2016c) from 3 nonpregnant midlactation multiparous Holstein cows $(\sim 160 \mathrm{~d}$ postpartum) to isolate PHEP. All cows were free of clinical and subclinical disease, but only 1 cow yielded cells that could be cultured in the laboratory. After briefly dipping in $70 \%$ ethanol for $30 \mathrm{~s}$ to reduce superficial contamination, liver tissue was transported to the laboratory within $30 \mathrm{~min}$ in $10-\mathrm{mL}$ sterile tubes containing $5 \mathrm{~mL}$ of HEPES with $0.05 \mathrm{~m} M$ EGTA. After being finely minced with a scalpel blade, the tissue was washed with $\mathrm{Ca}^{2+}$ - and $\mathrm{Mg}^{2+}$-free Hanks' balanced salt solution (HBSS; Corning, Manassas, VA) by centrifugation at $50 \times g$ for $3 \mathrm{~min}$ and resuspended in $50 \mathrm{~mL}$ of HBSS (Corning) containing $1 \mathrm{~m} M$ calcium chloride and $150 \mathrm{U} / \mathrm{mL}$ of type I collagenase (Sigma Chemical Co., St. Louis, MO). Subsequently, minced tissue was incubated with collagenase I for $40 \mathrm{~min}$ at $37^{\circ} \mathrm{C}$ with gentle shaking. At the end of incubation, $25 \mathrm{~mL}$ of medium containing $10 \%$ fetal bovine serum (Thermo Fisher Scientific, Waltham, MA) was added to neutralize collagenase. Cell suspensions were filtered through a 200 mesh cell strainer and washed with PBS for 3 times before re-suspending in growth medium [Dulbecco's modified Eagle medium (DMEM) supplemented with 10\% fetal 
bovine serum, $1 \mathrm{n} M$ glucagon, $10 \mathrm{n} M$ dexamethasone, $10 \mathrm{ng} / \mathrm{mL}$ epidermal growth factor, $10 \mathrm{n} M$ insulin, and $1 \%$ penicillin/streptomycin]. Approximately $1.0 \times 10^{6}$ to $2 \times 10^{6}$ cells were collected. The PHEP were seeded in T75 flasks at $3 \times 10^{5}$ cells per flask. Twenty-four hours after seeding, the medium was replaced with fresh growth medium.

\section{Identification of Hepatocytes in the PHEP Preparation}

A subset of hepatocyte marker genes were evaluated by RT-PCR. The RNA was extracted from cells and liver tissue using QIAzol Lysis Reagent (Qiagen, Valencia, CA) in the RNeasy Mini Kit (Qiagen) including an on-column treatment with DNase (SigmaAldrich, St. Louis, MO). The RNA integrity number assessed with the Agilent 2100 Bioanalyzer (Agilent Technologies, Santa Clara, CA) was greater than 8.0. The optical density at $260 / 280 \mathrm{~nm}$ ratio assessed with the NanoDrop ND-1000 spectrophotometer (NanoDrop Technologies, Wilmington, DE) was between 1.9 and 2.0. The mammary tissue sample was from the study of Batistel et al. (2018). The liver tissue sample was from the same cows from which PHEP were isolated. The cDNA from PHEP, liver tissue, and mammary tissue was synthesized from $1 \mu \mathrm{g}$ of total RNA using an oligo dT 18 primer (Invitrogen, Carlsbad, CA) according to the manufacturer's protocol. The PCR conditions were as follows: $94^{\circ} \mathrm{C}$ for $4 \mathrm{~min}, 35$ cycles of $94^{\circ} \mathrm{C}$ for $30 \mathrm{~s}, 60^{\circ} \mathrm{C}$ for $30 \mathrm{~s}$, and $72^{\circ} \mathrm{C}$ for $45 \mathrm{~s}$, and extension at $72^{\circ} \mathrm{C}$ for 10 min. The presence of a single PCR product was verified by the dissociation protocol using incremental temperatures to $95^{\circ} \mathrm{C}$ for $15 \mathrm{~s}$ plus $65^{\circ} \mathrm{C}$ for $15 \mathrm{~s}$. Each sample was run in triplicate and a 6-point relative standard curve (1:5 dilution) plus the nontemplate control was used (User Bulletin \#2, Applied Biosystems, Waltham, MA). The reactions were performed in an ABI Prism 7900 HT SDS instrument (Applied Biosystems). Data were calculated with the 7900 HT Sequence Detection Systems Software (version 2.2.1, Applied Biosystems). The PCR products were run on an agarose gel and visualized using an Eagle Eye Gel reader (ChemiDoc MP, Bio-Rad, Hercules, CA). Albumin ( $A L B), B H M T$, and cytochrome P450 1A1 (CYP1A1) were used as hepatocyte markers. The primer sequences used in this study are listed in Supplemental Table S1 (https://doi .org/10.3168/jds.2017-14236).

Flow cytometry was used to determine the percentage of cells expressing the hepatocyte-specific marker cytokeratin-18 (CK18; Wells et al., 1997; Decorsiere et al., 2016). Isolated PHEP at passage 3 were seeded in T75 flasks with growth medium for $24 \mathrm{~h}$. Subsequently, cells were fixed in $80 \%$ methanol ( $5 \mathrm{~min}$ ) and permeabilized with $0.1 \%$ PBS-Tween for $20 \mathrm{~min}$. The cells were then placed in $1 \times \mathrm{PBS} / 10 \%$ normal goat serum $/ 0.3 \mathrm{M}$ glycine to block nonspecific protein-protein interactions followed by addition of the CK18 antibody (catalog no. ab52459, Abcam, Cambridge, UK) and incubation for 30 min at $22^{\circ} \mathrm{C}$. Cells were kept in the dark on ice or at $4^{\circ} \mathrm{C}$ in a walk-in refrigerator until analysis. Cells were analyzed using a Becton Dickinson FACstar flow cytometer and CellQuest software (LSR II; Becton Dickinson, San Jose, CA).

\section{Treatments}

Isolated PHEP at passage 3 were seeded in 6 -well plates at $4 \times 10^{5}$ cells per well. Three hours postseeding, cells were switched to a maintenance medium [DMEM (catalog no. 31885-049, Thermo Fisher Scientific] supplemented with $0.2 \%$ fatty-acid-free BSA, $2 \mathrm{mM}$ sodium pyruvate, $0.1 \mu M$ dexamethasone, $1 \mathrm{n} M$ insulin, and $1 \%$ penicillin/streptomycin; Tavares et al., 2016) until $80 \%$ confluence was achieved. Before treatments, cells were incubated for $3 \mathrm{~h}$ with Met-free medium [DMEM (no Met) supplemented with $0.2 \%$ fatty-acid-free BSA, 2 $\mathrm{m} M$ sodium pyruvate, $0.1 \mu M$ dexamethasone, $1 \mathrm{n} M$ insulin, and $1 \%$ penicillin/streptomycin (Tavares et al., 2016)]. Methionine-free medium was used as a control (Con). Treatments were Met at $40 \mu M$ (Lapierre et al., 2012; Zhang et al., 2016) or Chol at $80 \mathrm{mg} / \mathrm{dL}$ added to the Met-free medium (Abdelmegeid et al., 2017). The Met level at $40 \mu M$ is a physiological concentration in portal vein of mid-lactation dairy cows (Lapierre et al., 2012). Work from our group (Abdelmegeid et al., 2017) and others (Chandler and White, 2017) indicated that a Chol concentration of $80 \mathrm{mg} / \mathrm{dL}$ was effective for studies of mRNA abundance in calf neutrophils and hepatocytes. Methionine as L-Met (Sigma-Aldrich) and Chol as choline chloride (Sigma-Aldrich) were used. For all treatments, cells were harvested after $24 \mathrm{~h}$ of culture. To further validate the PHEP culture system, incubations in Con or Met $(80 \mu M)$ medium were performed for 2,12 , or $24 \mathrm{~h}$ and used to measure concentrations of albumin (catalog no. MBS2000242, MyBioSource, San Diego, CA), urea (catalog no. 50-107-8333, BioAssay Systems, Hayward, CA), and activities of cytochrome P450 3A4 (Promega-Glo assay, catalog no. V8801, Promega Corp., Madison, WI; Li et al., 2018) and BHMT (Zhou et al., 2017; Table 1). In addition, gluconeogenesis from Na-propionate (P1880-100G, Sigma-Aldrich) was evaluated by measuring glucose concentration (Glucose Assay Kit, STA-681, Cell Biolabs Inc., San Diego, CA). Protocols for albumin, urea, and cytochrome P450 3A4 were as described by the manufacturers. 
Table 1. Concentrations of albumin and urea in culture medium, and activity of cytochrome P450 and betaine-homocysteine S-methyltransferase (BHMT) in primary liver cells enriched with hepatocytes after incubation with control medium or the control supplemented with $80 \mu M$ methionine $^{1}$

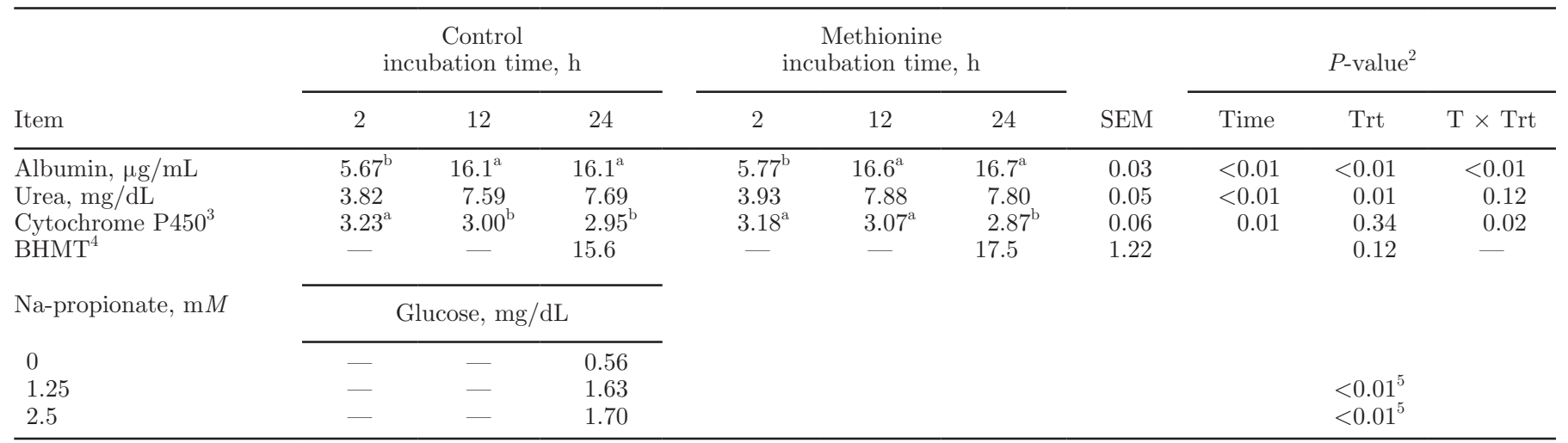

${ }_{\mathrm{a}, \mathrm{b}}$ Means with different superscripts differ across time $(\mathrm{T} \times \mathrm{Trt}, P<0.05)$.

${ }^{1}$ Concentration of glucose in culture medium was evaluated in response to supplementation of basal medium (Dulbecco's modified Eagle medium) with Na-propionate and after $24 \mathrm{~h}$ of culture.

${ }^{2} \mathrm{Trt}=$ treatment effect; $\mathrm{T} \times \mathrm{Trt}=$ time by treatment interaction.

${ }^{3}$ Fold induction relative to control wells on assay plate not receiving enzyme induction reagent.

${ }^{4}$ Nanomoles of product/h per mg of protein.

${ }^{5} P$-value relative to the control.

\section{RNA Extraction, cDNA Synthesis, and Real-Time PCR Analysis of Target Genes}

Total RNA extraction was performed with the miRNeasy kit (Qiagen, Valencia, CA) according to the manufacturer's instructions. Samples for reversetranscription (RT)-PCR had an RNA integrity number $\geq 8.0$ (Agilent Bioanalyzer), and a portion of each was diluted to $100 \mathrm{ng} / \mu \mathrm{L}$ with RNase-free water before cDNA synthesis. Each sample was run in triplicate and a 6-point relative standard curve (1:5 dilution) plus the nontemplate control was used (User Bulletin \#2, Applied Biosystems). Reverse transcription was performed essentially as described previously (Osorio et al., 2014a). For real-time PCR (qPCR), $4 \mu \mathrm{L}$ of diluted cDNA was combined with $6 \mu \mathrm{L}$ of a mixture composed of $5 \mu \mathrm{L}$ of $1 \times$ SYBR Green Master Mix (Quanta, Gaithersburg, $\mathrm{MD}), 0.4 \mu \mathrm{L}$ each of $10 \mu M$ forward and reverse primers, and $0.2 \mu \mathrm{L}$ of RNase-free water. The qPCR was performed in $10-\mu \mathrm{L}$ reactions containing $4 \mu \mathrm{L}$ of diluted cDNA and $6 \mu \mathrm{L}$ of a mixture composed of $5 \mu \mathrm{L}$ of $1 \times$ SYBR Green Master Mix (Quanta). Reaction mixtures were preheated at $95^{\circ} \mathrm{C}$ for $5 \mathrm{~min}$, followed by 40 cycles of melting at $94^{\circ} \mathrm{C}$ for $15 \mathrm{~s}$, annealing at $60^{\circ} \mathrm{C}$ for $30 \mathrm{~s}$ (ABI Prism 7900 HT SDS instrument, Applied Biosystems). The standard curve method and QuantStudio 7 Flex Real-Time PCR Software (Applied Biosystems) were used for data analysis. Internal controls were $18 \mathrm{~S}$ ribosomal RNA (RN18S1), ubiquitously expressed prefoldin-like chaperone $(U X T)$, and serine and arginine rich splicing factor 4 (SFRS4). Among 8 candi- dates tested (RN18S1, ACTB, GUSB, RPS15, SFRS4, GAPDH, RPS9, UXT), these had the lowest coefficient of variation during $\mathrm{qPCR}$. Their geometric mean was used to normalize the mRNA abundance data. The primer sequences used in this study are listed in Supplemental Table S2 (https://doi.org/10.3168/jds.2017 -14236). Except for RNA18S1, SFRS4, and CYP1A1 (Supplemental Table S2), all other primer sequences used are described in Zhou et al. (2017). Primer design and evaluation were performed as described previously (Bionaz and Loor, 2007).

\section{Western Blotting}

Cells ( $\mathrm{n}=3 /$ treatment) were washed 3 times with ice-cold PBS. Total protein was extracted using a mammalian protein extraction reagent (catalog no. 78501, Thermo Fisher Scientific), which included an inhibitor cocktail (catalog no. 78442, Thermo Fisher Scientific). The protein concentrations were determined using the BCA protein assay kit (catalog no. 23227, Thermo Fisher Scientific), and then $20 \mu \mathrm{g}$ of total protein diluted with $4 \times$ Laemmli sample buffer (catalog no. 161-0747, Bio-Rad) at a $3: 1$ ratio and boiled at $100^{\circ} \mathrm{C}$ for $10 \mathrm{~min}$. Sixty micrograms of protein was resolved in 4 to $20 \%$ Mini-Protean TGX precast gels (catalog no. 4561096, Bio-Rad) and then transferred to a PVDF membrane (catalog no. 1620261, Bio-Rad) using a semi-dry transfer assembly (catalog no. 221BR, Bio-Rad). The membranes were blocked with $5 \%$ skim milk in Tris-buffered saline (TBS) at room temperature for $2 \mathrm{~h}$, and then 
incubated overnight with the primary antibodies for BHMT, CBS, PEMT, and methionine adenosyltransferase 1A (MAT1A; catalog no. AV41474, AV45746, AV41398, AV43558, respectively; Sigma-Aldrich, St. Louis, MO). After incubation with primary antibody, the membranes were subsequently washed 6 times (10 min each) and incubated with horesradissh peroxidase (HRP) AffiniPure goat anti-rabbit IgG (catalog no. ab6721; Abcam) in TBS-Tween (TBST; 1:10,000, vol: vol) for $1 \mathrm{~h}$ at room temperature, washed 6 times (10 min each), and then incubated with the Clarity Western ECL Substrate (catalog no. 170-5060, Bio-Rad).

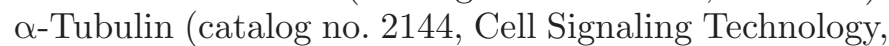
Danvers, MA) was the internal control. Band intensities were captured using an imaging system (ChemiDoc MP, Bio-Rad) and analyzed using Image Lab 5.2.1 (Bio-Rad).

\section{Statistical Analysis}

All data were analyzed using the mixed model procedure of SAS (version 9.4, SAS Institute Inc., Cary, NC) according to the following model:

$$
\mathrm{Y}_{\mathrm{ij}}=\mu+\mathrm{T}_{\mathrm{i}}+\mathrm{A}_{\mathrm{j}}+\mathrm{e}_{\mathrm{ij}},
$$

where $\mathrm{Y}$ are observations for dependent variables, $\mu$ is the general mean, $\mathrm{T}_{\mathrm{i}}$ is the fixed effect of treatment, $A_{j}$ is the random effect of wells, and $e_{i j}$ is the random error. Data for albumin, urea, and cytochrome P450 were handled in the same fashion but the statistical model included the fixed effect of treatment (Con or Met), time $(2,12$, or $24 \mathrm{~h})$, and the interactions of treatment $\times$ time. Variables were assessed for normality of distribution using the Shapiro-Wilk test. When the normality assumption was rejected, data were logtransformed before statistical analysis. The statistical significance level was set at $P<0.05$.

\section{RESULTS}

\section{Characterization of Primary Liver Cells Enriched in Hepatocytes}

The RT-PCR analysis confirmed that these cells expressed a subset of hepatocyte-specific genes $(A L B$, $B H M T$, and $C Y P 1 A 1$; Figure 1A). The flow cytometry assay revealed $91 \%$ of cultivated PHEP were positive for the hepatocyte marker CK18 (Figure 1B). The PHEP stained with hematoxylin after d 2 of culture are shown in Supplemental Figure S1 (https://doi.org/ 10.3168/jds.2017-14236). In addition, concentrations of albumin and urea were greater $(P<0.01)$ overall in PHEP cultured with Met compared with Con (Table
1). Similarly, the concentration of glucose increased after incubations with Na-propionate even though the culture medium already contained glucose $(5.56 \mathrm{mM}$; "low-glucose" DMEM). Although activities of cytochrome P450 $(P=0.34)$ and BHMT $(P=0.12)$ did not differ in response to Met, the fact that these enzymes are abundant in liver tissue (Zhou et al., 2017) or hepatocytes (Garrow, 1996) provided further support for the viability of these cells and enrichment of hepatocytes to undertake the present study.

\section{Methionine and Chol Metabolism in the Transmethylation Pathway: Effects on mRNA Abundance}

The mRNA abundance of MAT1A and PEMT was greater in PHEP treated with Met compared with Chol and Con $(P<0.05$; Figure 2). Given its role in the metabolism of Met, it is noteworthy that methionine adenosyltransferase 2A (MAT2A) mRNA abundance was greater in response to Chol compared with Con or Met $(P<0.05)$.

Among the components of homocysteine remethylation, enhancing the supply of Met resulted in upregulation of BHMT, sarcosine dehydrogenase (SARDH), and S-adenosylhomocysteine hydrolase $(S A H H)$ compared with Con or Chol $(P<0.05)$. Although MTR expression was greater in PHEP treated with Met or Chol $(P<0.05)$, the overall abundance of 5,10 methylenetetrahydrofolate reductase $(M T H F R)$ did not differ $(P>0.05)$.

Among components of the oxidative pathway of Chol to betaine, compared with Con, Met, and Chol upregulated the mRNA abundance of betaine aldehyde dehydrogenase $(B A D H ; P<0.05)$. In contrast, choline dehydrogenase $(C H D H)$ abundance was greater in PHEP receiving supply of Chol compared with Met and Con $(P<0.05)$. In addition, enhancing supply of Met also upregulated $C H D H$ compared with Con $(P<$ $0.05)$.

\section{Methionine and Choline Metabolism in the CDP. Choline Pathway: Effects on mRNA Abundance}

Abundance of both choline kinase $\alpha(C H K A)$ and choline kinase $\beta(C H K B)$ was greater in response to Chol supply compared with Met or Con $(P<0.05$; Figure 3). Although phosphate cytidylyltransferase 1, choline, $\beta$ (PCYT1B) abundance was not affected by Met or Chol $(P>0.05)$, phosphate cytidylyltransferase 1, choline, $\alpha(P C Y T 1 A)$ was greater in PHEP receiving supply of Chol compared with Met and Con $(P<0.05)$. In fact, Met supply resulted in the lowest abundance of PCYT1A $(P<0.05)$. In addition, choline/ethanol- 
amine phosphotransferase 1 (CEPT1) abundance was greater in response to supply of Chol compared with Met or Con $(P<0.05)$.

\section{Methionine and Choline Metabolism in the Transsulfuration Pathway: Effects on mRNA Abundance}

Among enzymes involved in the transsulfuration pathway, we observed no differences $(P>0.05)$ between Con and Chol for cystathionine $\beta$-synthase $(C B S)$ abundance (Figure 4). However, abundance was greater in PHEP receiving supply of Met compared with Con and Chol $(P<0.05$; Figure 3$)$. Although cysteine dioxygenase 1 (CDO1) expression was not affected by Met or Chol $(P>0.05)$, abundance of cysteine sulfinic acid decarboxylase $(C S A D)$, glutamate-cysteine ligase, catalytic subunit $(G C L C)$, and glutathione reductase $(G S R)$ was greater in response to Met supplementation compared with Con and Chol $(P<0.05)$. It was noteworthy that, whereas Chol supply resulted in the greatest abundance of glutathione synthase ( $G S S ; P<$ 0.05), PHEP receiving supply of Met had lower abundance of GSS compared with Con $(P<0.05)$.

\section{Methionine and Choline Metabolism and Their Effect on Protein Abundance}

The protein level of MAT1A and PEMT was greater in PHEP treated with Met $(P<0.05$, Figure 5$)$, which agreed with the mRNA abundance data. Similarly, in agreement with mRNA abundance, the protein abundance of BHMT was greater overall in PHEP receiving supply of Met $(P<0.05$, Figure 3$)$. The protein abun-
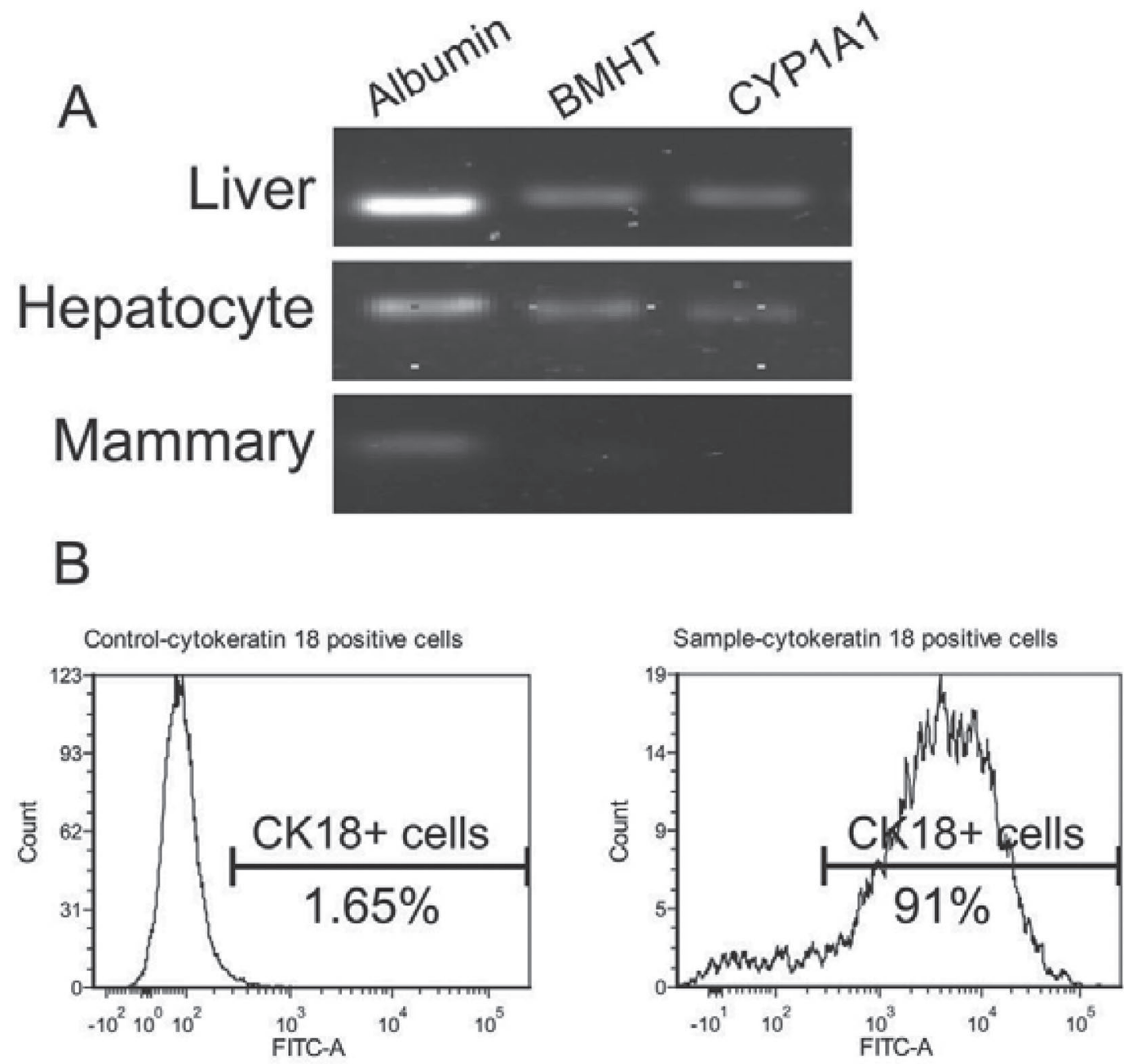

Figure 1. mRNA abundance of selected hepatocyte marker genes. Albumin $(A L B)$, betaine-homocysteine S-methyltransferase $(B H M T)$, and cytochrome P450 1A1 (CYP1A1) abundance was detected in liver tissue, primary liver cells enriched with hepatocytes (hepatocyte), and mammary gland tissue for comparison (A). Flow cytometry results depicting the expression of cytokeratin 18 (CK18; B). 
dance of CBS was greater in PHEP receiving supply of Met compared with Con and Chol $(P<0.05)$, which agreed with the mRNA abundance data.
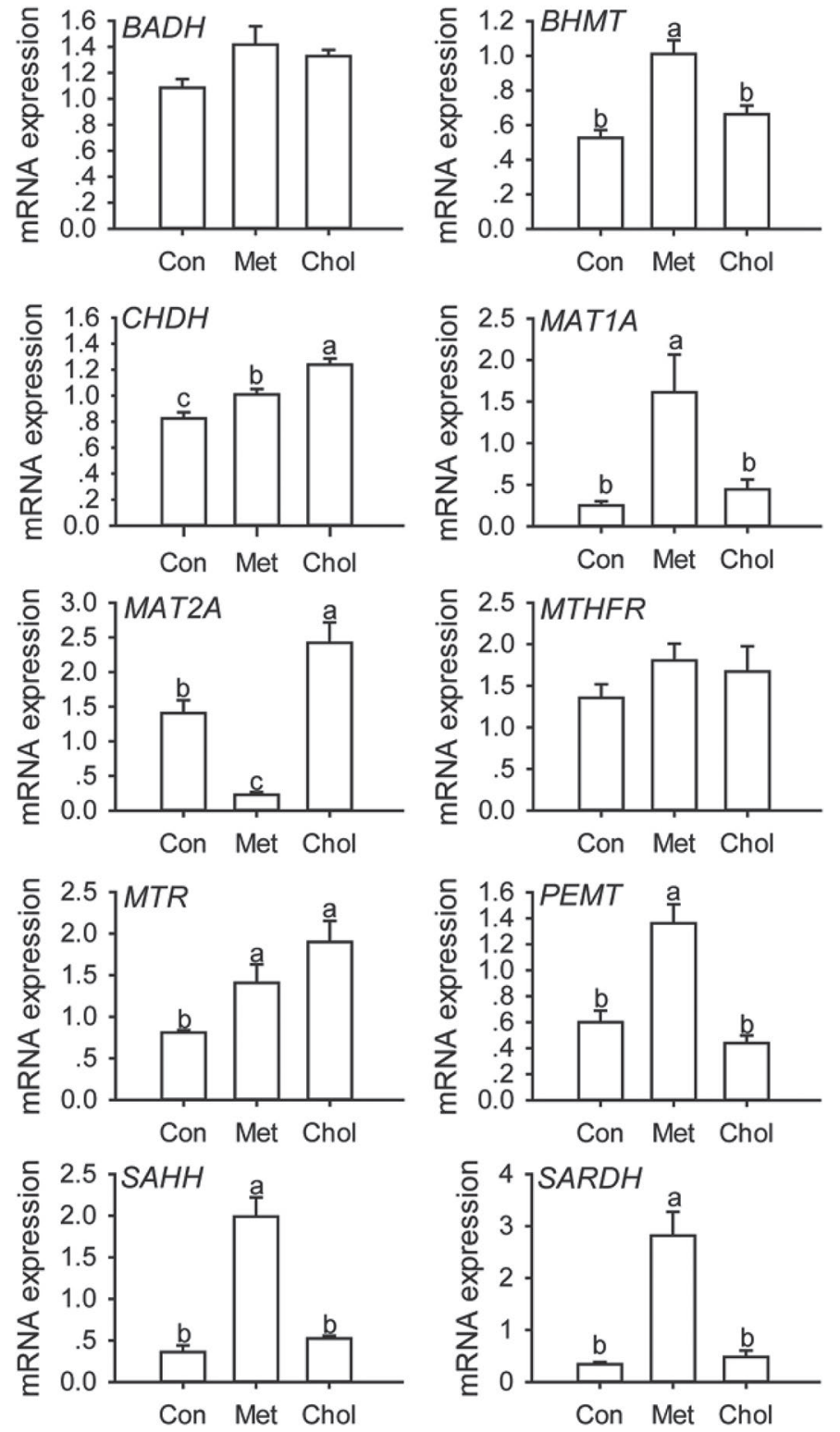

Figure 2. Effect of Met or choline (Chol) supply on abundance of genes encoding enzymes related to transmethylation in primary liver cells enriched with hepatocytes (PHEP). The PHEP were cultured with Met $(40 \mu \mathrm{M})$ or Chol $(80 \mathrm{mg} / \mathrm{dL})$ for $24 \mathrm{~h}$ and harvested for mRNA abundance. The experiment was repeated 3 times. Different letters $(\mathrm{a}-\mathrm{c})$ indicate significant differences between groups $(P<0.05)$. $B A D H=$ betaine aldehyde dehydrogenase; $B H M T=$ betaine homocysteine methyltransferase; $C H D H=$ choline dehydrogenase; $M A T 1 A$ $=$ methionine adenosyltransferase $1 \mathrm{~A} ; M A T 2 A=$ methionine adenosyltransferase $2 \mathrm{~A} ; M T H F R=$ methylenetetrahydrofolate reductase $M T R=5$-methyltetrahydrofolate-homocysteine methyltransferase; $P E M T=$ phosphatidylethanolamine methyltransferase; $S A H H=$ S-adenosylhomocysteine hydrolase; $S A R D H=$ sarcosine dehydrogenase. Error bars represent the SEM.
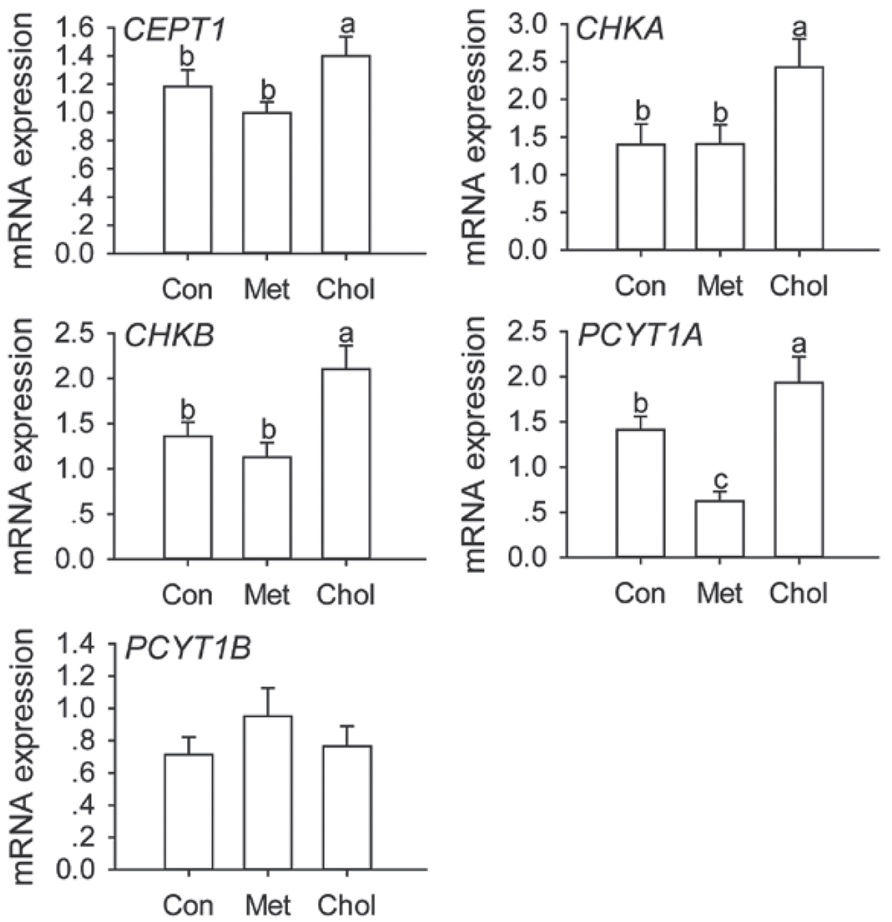

Figure 3. Effect of Met or choline (Chol) supply on abundance of genes encoding key enzymes related to the cytidine 5'-diphosphocholine pathway in primary liver cells enriched with hepatocytes (PHEP). The PHEP were cultured with Met $(40 \mu M)$ or Chol $(80 \mathrm{mg} / \mathrm{dL})$ for 24 $\mathrm{h}$ and harvested for mRNA abundance. The experiment was repeated 3 times. Different letters $(\mathrm{a}-\mathrm{c})$ indicate significant differences between groups $(P<0.05)$. CEPT1 $=$ choline/ethanolamine phosphotransferase $1 ; C H D H=$ choline dehydrogenase; $C H K A=$ choline kinase $\mathrm{A}$; $C H K B=$ choline kinase $\mathrm{B}$; $P C Y T 1 A=$ phosphate cytidylyltransferase $1 \mathrm{~A} ; P C Y T 1 B=$ phosphate cytidylyltransferase 1B. Error bars represent the SEM.

\section{DISCUSSION}

\section{Isolation and Characterization of Primary Liver Cells Enriched with Hepatocytes}

Hepatocytes isolated by perfusion and requiring sacrifice of the animal are highly differentiated cells that quickly lose their ability to regenerate and function (Lemley and Wilson, 2010). Although hepatocyte isolation from neonatal dairy calves via perfusion methods have been performed previously (e.g., Chandler and White, 2017), results from a recent whole-transcriptome analysis revealed seemingly distinct properties in liver of neonatal dairy calves compared with adult dairy cows (Batistel et al., 2016). In light of these issues, we attempted to isolate PHEP using a nonperfusion method in liver biopsy samples based on methods reported previously (Lemley and Wilson, 2010). In terms of purity, $91 \%$ of isolated PHEP were cytokeratin-18 positive, indicating high purity of primary cells and hepatocytes. The high expression, along with measurable activity of cytochrome P450 and BHMT, of BHMT 
and $C Y P 1 A 1$ provided additional confirmation of the purity and viability of the isolated PHEP. Both BHMT and cytochrome $\mathrm{P} 450$ are specific and highly expressed in liver or hepatocytes (Schweikl et al., 1993; Pellanda et al., 2012; Li et al., 2018). With regard to functional properties, the increase in albumin, an important liverspecific functional marker (Spotorno et al., 2006), and urea concentrations in response to Met supplemented further confirmed the viability of the PHEP cell extract. Lastly, despite the fact that culture medium already contained a much greater amount of glucose ( $5.56 \mathrm{~m} M$ or $100 \mathrm{mg} / \mathrm{dL}$ ) relative to what is typical in blood of dairy cows $(55-65 \mathrm{mg} / \mathrm{dL})$, the PHEP preparation responded to Na-propionate supplementation, again suggesting enrichment with hepatocytes.

\section{One-Carbon Metabolism}

The role of the 1-carbon and Met metabolism pathways as metabolic integrators of nutrient status has been extensively studied in model organisms (mouse, rat) and humans (Locasale, 2013). Methionine and
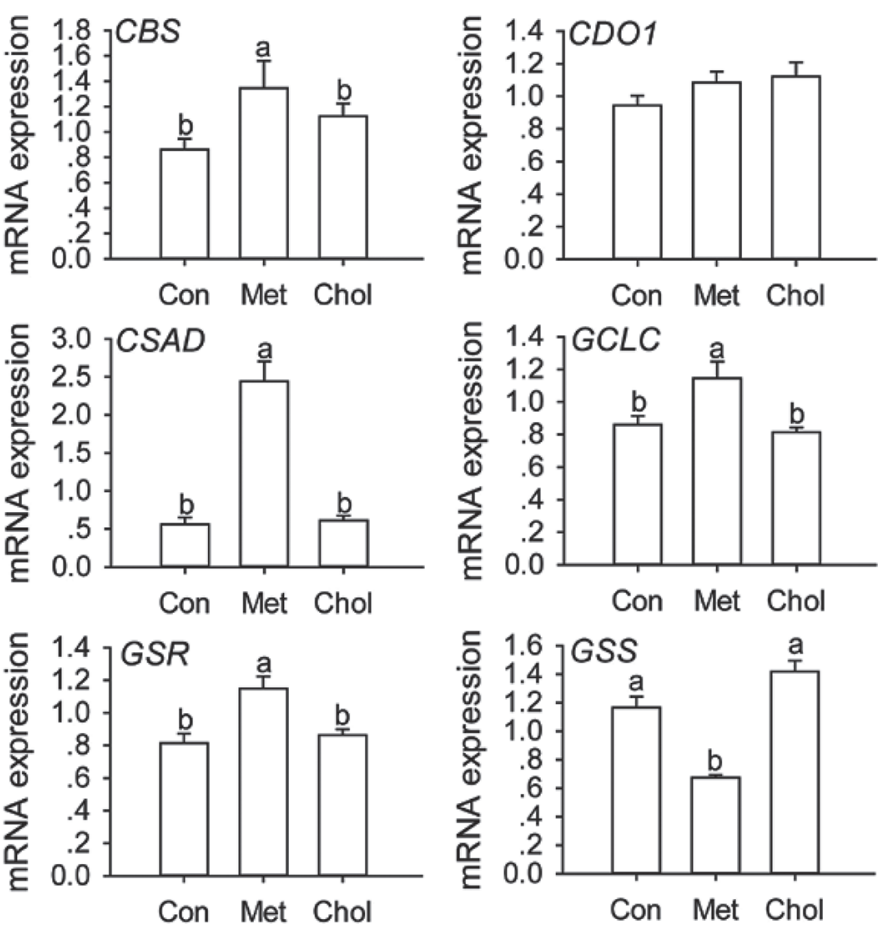

Figure 4. Effect of Met or choline (Chol) supply on abundance of key genes encoding enzymes related to transsulfuration in primary liver cells enriched with hepatocytes (PHEP). The PHEP were cultured with Met $(40 \mu M)$ or Chol $(80 \mathrm{mg} / \mathrm{dL})$ for $24 \mathrm{~h}$ and harvested for mRNA abundance. The experiment was repeated 3 times. Different letters $(\mathrm{a}, \mathrm{b})$ indicate significant differences between groups $(P<0.05)$. $C B S=$ cystathionine $\beta$-synthase; $C D O=$ cysteine dioxygenase; $C S A D$ $=$ cysteine sulfinic acid decarboxylase; $G C L C=$ glutamate-cysteine ligase $=$ catalytic subunit; $G S R=$ glutathione reductase; $G S S=$ glutathione synthase. Error bars represent the SEM.
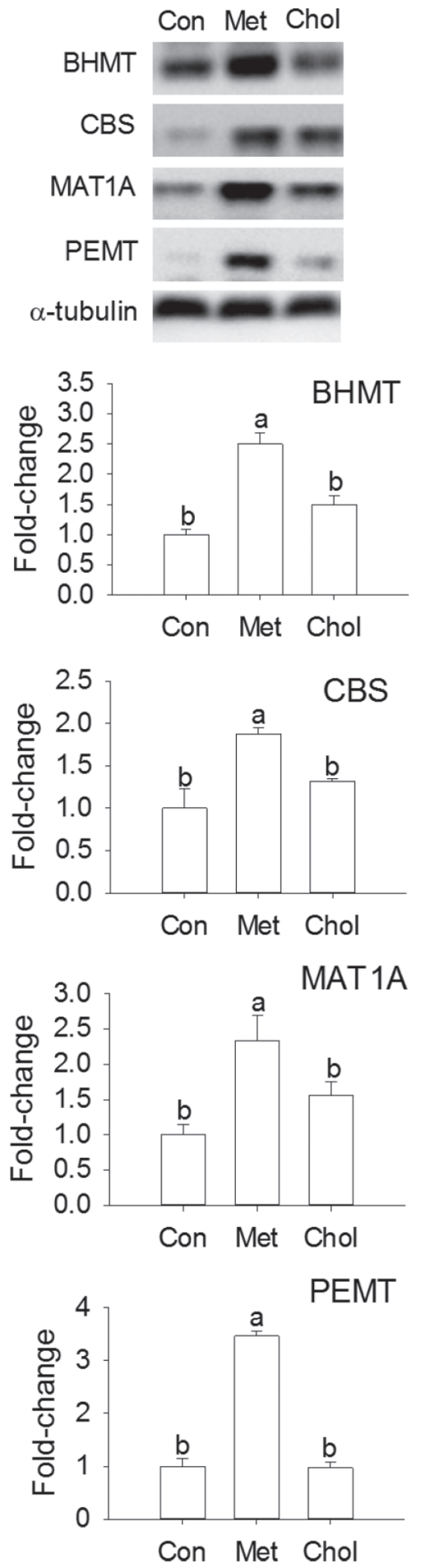

Figure 5. Effect of Met or choline (Chol) supply on protein abundance of key enzymes in the transmethylation, transsulfuration, and cytidine $5^{\prime}$-diphosphocholine pathway in primary liver cells enriched with hepatocytes (PHEP). The PHEP were cultured with Met (40 $\mu M)$ or Chol $(80 \mathrm{mg} / \mathrm{dL})$ for $24 \mathrm{~h}$ and harvested for protein abundance. The experiment was repeated 3 times. Different letters $(\mathrm{a}, \mathrm{b})$ indicate significant differences between groups $(P<0.05)$. BHMT $=$ betaine homocysteine methyltransferase; $\mathrm{CBS}=$ cystathionine $\beta$-synthase; MAT1A = methionine adenosyltransferase 1A; PEMT = phosphatidylethanolamine methyltransferase. Error bars represent the SEM. 
Chol are 2 important and closely interrelated methyl donors that exert regulation of the pathway via different mechanisms. Previous work with dairy cows has demonstrated a positive effect of Met supply during the periparturient period on health and production performance, including alleviation of inflammation and oxidative stress (Osorio et al., 2014b; Sun et al., 2016; Zhou et al., 2016a,b, 2017; Batistel et al., 2017, 2018). In some, but not all (Zhou et al., 2016a,c; Zenobi et al., 2018), studies with rumen-protected Chol, lactation performance and antioxidant capacity and immune function of dairy cows has been improved (Zom et al., 2011; Lima et al., 2012; Sun et al., 2016). Although gene expression and enzyme activity data suggested that Chol supplementation did not alter Met synthesis (Zhou et al., 2017), a better assessment of underlying mechanisms is challenging to address in vivo. Thus, an important aim of the present study was to isolate and culture primary liver cells enriched in hepatocytes from dairy cows (instead of dairy calves; Zhang et al., 2016; Chandler and White, 2017) and evaluate alterations in mRNA and protein abundance of components of the 1-carbon, Met, and transsulfuration pathways in response to supply of Met or Chol.

S-Adenosylmethionine is an intermediate metabolite in the Met metabolism pathway and an important substrate for hepatic synthesis of PC and S-adenosyl homocysteine (Martinov et al., 2010). The reaction leading to SAM synthesis from Met is catalyzed by MAT1, which is the product of 2 different genes, MAT1A and MAT2A, encoding 2 distinct enzymes (Garcia-Trevijano et al., 2000). Although MAT1A and MAT2A catalyze the same reaction, they display distinct catalytic and regulatory properties that affect intracellular concentrations of SAM (Gambhir, 2000). The greater mRNA and protein of MAT1A in Met-treated PHEP suggest an elevated concentration of SAM in response to supply of Met. This idea is supported in part by data from HepG2 cells in which MAT1A expression was positively associated with high SAM concentrations (MartinezChantar et al., 2003). In contrast, MAT2A expression was reported to be negatively correlated with hepatic SAM concentrations (Martinez-Chantar et al., 2003). Thus, the lower MAT2A abundance observed in Mettreated PHEP suggests a less significant role of MAT2A in bovine hepatic SAM metabolism. The enzyme PEMT catalyzes the sequential transfer of 3 methyl groups from SAM to phosphatidylethanolamine to generate PC and SAHH (Fernandez-Arroyo et al., 2016). Similar to MAT1A abundance, the fact that PEMT abundance also increased in PHEP cultured with Met is additional evidence that availability of SAM for PC synthesis might have been increased.
The upregulation of $M T R$ abundance with Met or Chol along with upregulation of $S A H H$ abundance with Met indicated that homocysteine and potentially 5-methyltetrahydrofolate synthesis increased (Tavares et al., 2016). In vivo, both MTR and BHMT can catalyze the remethylation of homocysteine to Met (Pellanda et al., 2012). However, judging from in vivo data with dairy cows, there have been mixed results on hepatic MTR abundance in response to greater Met supply [i.e., upregulation of its mRNA (Osorio et al., 2014a) or lack of change (Zhou et al., 2017)]. In a recent study, increasing concentrations of exogenous Met in vitro $(16,30$, 100 , or $300 \mu M)$ decreased MTR expression linearly in neonatal calf hepatocytes (Chandler and White, 2017), underscoring the potential for feedback inhibition of the enzyme. Whether such effect is relevant in vivo is unknown. However, it seems unlikely that during lactation when the mammary gland is a prime user of Met its intracellular concentrations within hepatocytes would reach an inhibitory concentration.

The greater mRNA and protein abundance of BHMT in response to Met, but not Chol, supplementation was somewhat unexpected given that Chol oxidation to generate dimethyl glycine requires BHMT. The mechanisms behind the positive effect of Met on BHMT are unknown, but might be related to steps generating SAM and SAHH followed by transsulfuration (Finkelstein et al., 1982).

The present data seem to support a preferential utilization of Met via the Met and transsulfuration pathways such that generation of SAM might have been curtailed, hence the need for BHMT activity to increase. The greater mRNA abundance of $C H D H$ and $B A D H$ with Chol supply indicated that under those conditions the amount of betaine generated might have been enough to generate SAM and also homocysteine to regenerate Met via MTR (also upregulated with Chol).

\section{CDP-Choline Pathway}

Phosphatidylcholine is necessary for the packaging and export of triacylglycerol in VLDL (Corbin and Zeisel, 2012). Choline kinase catalyzes the first reaction in PC synthesis via the Kennedy pathway (Soto and Carman, 2008) and is encoded by $C H K A$ and $C H K B$ (Wu and Vance, 2010). The observed upregulation of those genes in PHEP receiving Chol supply supports the idea that synthesis of PC might have been increased. This idea is supported by the fact that Chol upregulated PCYT1A and CEPT1 [i.e., Chol supplementation might have led to greater availability of CDP-choline to synthesize PC via the Kennedy pathway as demonstrated previously (Sugimoto et al., 2008)]. Our previous data with di- 
etary rumen-protected Chol supplementation supports this sequence of events (Zhou et al., 2017). For several years (e.g., Pinotti et al., 2002), the focus on Chol supply to periparturient cows has been on increasing PC synthesis in liver to prevent hepatic lipid accumulation, and results from the present study confirmed that supplemental Chol was mainly metabolized through the CDP-choline pathway. The majority of Chol is metabolized through the CDP-choline pathway in ruminants and rodents, and in the former it is largely ascribed to the lower transmethylation rates (Snoswell and Xue, 1987; Zeisel and Blusztajn, 1994). Taken together, as proposed previously (Goselink et al., 2013), the data suggest that exogenous Chol may potentially increase VLDL export in part through the generation of $\mathrm{PC}$ via the CDP pathway.

\section{Transsulfuration Pathway}

The enzyme CBS catalyzes the conversion of homocysteine to cystathionine in the first step of the transsulfuration pathway (Jhee and Kruger, 2005). The marked increase in mRNA and protein abundance of CBS in response to Met supplementation indicated the potential for greater flux of homocysteine into cysteine followed by synthesis of glutathione and taurine (Brosnan and Brosnan, 2006). The enzymes CDO1 and CSAD are 2 rate-limiting enzymes in de novo taurine synthesis (Park et al., 2014), and their expression is positively associated with taurine levels in the liver (Ma et al., 2015). Despite the lack of change in abundance of $C D O 1$ in response to Met or Chol, the marked upregulation of $C S A D$ abundance in Met-supplemented PHEP suggests that synthesis of taurine might have been increased (Osorio et al., 2014a).

The central role of glutathione as an antioxidant or conjugate in detoxification reactions has been extensively characterized in nonruminants. This compound is synthesized in a 2-step process catalyzed by GCLC and GSS (Lushchak, 2012). Previous in vivo studies with dairy cows have consistently demonstrated an increase in glutathione synthesis in response to Met supplementation (Osorio et al., 2013; Zhou et al., 2016a, 2017; Batistel et al., 2017, 2018), and this response was closely associated with upregulation of mRNA abundance of $C B S$ (Zhou et al., 2017). Thus, besides the positive response on CBS mRNA and protein abundance, the upregulation of $G C L C$ and $G S R$ in response to Met

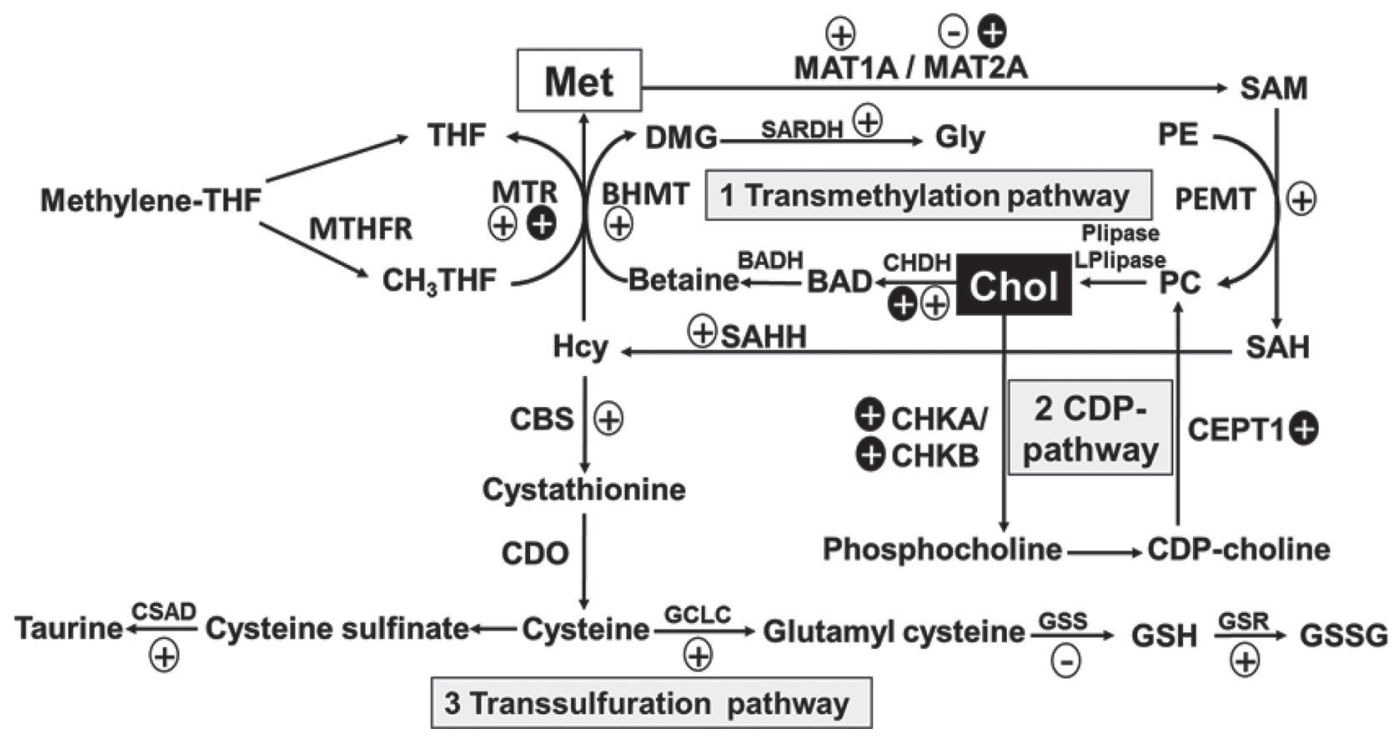

Figure 6. Reconstruction of transmethylation, transsulfuration, and cytidine 5'-diphosphocholine (CDP-choline) pathways based on genes and proteins measured in the present study. Positive and negative signs with white background indicate responses detected in primary liver cells enriched with hepatocytes (PHEP) cultured with Met. Positive and negative signs with black background indicate responses detected in PHEP cultured with choline (Chol). Oxidation of Chol to betaine as part of the transmethylation pathway (Craig, 2004) and synthesis of Chol from phosphatidylcholine (PC) to Chol via phospholipases (Plipase) and lysophospholipaes (LPlipase; Li and Vance, 2008) have been discussed. $\mathrm{BAD}=$ betaine aldehyde; $\mathrm{BADH}=$ betaine aldehyde dehydrogenase; BHMT $=$ betaine homocysteine methyltransferase; CBS $=$ cystathionine $\beta$-synthase $\mathrm{CDO}=$ cysteine dioxygenase CEPT1 = choline/ethanolamine phosphotransferase $1 ; \mathrm{CHDH}=$ choline dehydrogenase; $\mathrm{CHKA}=$ choline kinase $\mathrm{A} ; \mathrm{CHKB}=$ choline kinase $\mathrm{B} ; \mathrm{CH}_{3} \mathrm{THF}=5$-methyltetrahydrofolate; $\mathrm{CSAD}=$ cysteine sulfinic acid decarboxylase; $\mathrm{DMG}=$ dimethylglycine; GCLC = glutamate-cysteine ligase = catalytic subunit; Gly = glycine; GSH = glutathione; GSSG = glutathione disulfide; $\mathrm{GSR}=$ glutathione reductase; GSS = glutathione synthase; Hcy = homocysteine; MAT1A = methionine adenosyltransferase 1A; MAT2A = methionine adenosyltransferase 2A; MTHFR = methylenetetrahydrofolate reductase; MTR $=5$-methyltetrahydrofolate-homocysteine methyltransferase; PCYT1A = phosphate cytidylyltransferase 1A; PCYT1B = phosphate cytidylyltransferase 1B; PE = phosphatidylethanolamine; PEMT $=$ phosphatidylethanolamine methyltransferase; $\mathrm{SAH}=\mathrm{S}$-adenosylhomocysteine; $\mathrm{SAHH}=\mathrm{S}$-adenosylhomocysteine hydrolase; SAM $=$ S-adenosylmethionine; SARDH = sarcosine dehydrogenase; THF = tetrahydrofolate. 
supplementation underscores the importance of these genes in the overall steps leading to greater glutathione synthesis. It is noteworthy that expression of GSS was lower in Met-supplemented PHEP, which we speculate was due to increased glutathione concentration-induced feedback inhibition on GSS.

\section{CONCLUSIONS}

Overall, our findings provide evidence that enhancing the supply of Met or Chol to dairy cow PHEP in vitro affects the mRNA and protein expression of key components of the transmethylation, transsulfuration, and CDP-choline pathways (Figure 6). Transmethylation and transsulfuration appear more responsive to Met supply, whereas the CDP-choline pathway is more responsive to Chol supply. However, because isolated primary cells are by design manipulated outside their normal environment (no surrounding tissues, no physiological change, no stressors), the relevance of these data in vivo merit further study.

\section{ACKNOWLEDGMENTS}

Y. Zhou received a China Scholarship Council (Beijing) postdoctoral fellowship to train at the University of Illinois (Urbana). Fernanda Batistel was supported by a fellowship from Coordenação de Aperfeiçoamento de Pessoal de Nível Superior (CAPES, Brazilian Ministry of Education, Brasília, Brazil) and by Hatch funds under project ILLU-538-914, National Institute of Food and Agriculture (Washington, DC). Support for the conduct of the project was provided by Hatch funds under project ILLU-538-914.

\section{REFERENCES}

Abdelmegeid, M. K., M. Vailati-Riboni, A. Alharthi, F. Batistel, and J. J. Loor. 2017. Supplemental methionine, choline, or taurine alter in vitro gene network expression of polymorphonuclear leukocytes from neonatal Holstein calves. J. Dairy Sci. 100:3155-3165.

Batistel, F., J. Arroyo, C. Garces, E. Trevisi, C. Parys, M. Ballou, F. Cardoso, and J. Loor. 2018. Ethyl-cellulose rumen-protected methionine alleviates inflammation and oxidative stress and improves neutrophil function during the periparturient period and early lactation in Holstein dairy cows. J. Dairy Sci. 101:480-490. https:// doi.org/10.3168/jds.2017-13185.

Batistel, F., J. M. Arroyo, A. Bellingeri, L. Wang, B. Saremi, C. Parys, E. Trevisi, F. C. Cardoso, and J. J. Loor. 2017. Ethyl-cellulose rumen-protected methionine enhances performance during the periparturient period and early lactation in Holstein dairy cows. J. Dairy Sci. 100:7455-7467.

Batistel, F., M. Vailati-Riboni, A. Agrawal, and J. J. Loor. 2016. Transcriptome analysis reveals fundamental differences between liver of neonatal calves and transition dairy cows. J. Dairy Sci. 99(E-Suppl. 1):1104. (Abstr.)

Bionaz, M., and J. J. Loor. 2007. Identification of reference genes for quantitative real-time PCR in the bovine mammary gland during the lactation cycle. Physiol. Genomics 29:312-319.
Brosnan, J. T., and M. E. Brosnan. 2006. The sulfur-containing amino acids: An overview. J. Nutr. 136:1636S-1640S.

Chandler, T. L., and H. M. White. 2017. Choline and methionine differentially alter methyl carbon metabolism in bovine neonatal hepatocytes. PLoS One 12:e0171080.

Corbin, K. D., and S. H. Zeisel. 2012. Choline metabolism provides novel insights into nonalcoholic fatty liver disease and its progression. Curr. Opin. Gastroenterol. 28:159-165.

Craig, S. A. 2004. Betaine in human nutrition. Am. J. Clin. Nutr. 80:539-549.

Decorsiere, A., H. Mueller, P. C. van Breugel, F. Abdul, L. Gerossier, R. K. Beran, C. M. Livingston, C. Niu, S. P. Fletcher, O. Hantz, and M. Strubin. 2016. Hepatitis B virus X protein identifies the Smc5/6 complex as a host restriction factor. Nature 531:386-389.

Ducker, G. S., and J. D. Rabinowitz. 2017. One-carbon metabolism in health and disease. Cell Metab. 25:27-42.

Fernandez-Arroyo, S., E. Cuyas, J. Bosch-Barrera, T. Alarcon, J. Joven, and J. A. Menendez. 2016. Activation of the methylation cycle in cells reprogrammed into a stem cell-like state. Oncoscience 2:958-967.

Finkelstein, J. D., B. J. Harris, J. J. Martin, and W. E. Kyle. 1982. Regulation of hepatic betaine-homocysteine methyltransferase by dietary methionine. Biochem. Biophys. Res. Commun. 108:344348.

Gambhir, J. K. 2000. Homocysteine metabolism in health and disease. Indian Heart J. 52:S9-S15.

Garcia-Trevijano, E. R., M. U. Latasa, M. V. Carretero, C. Berasain, J. M. Mato, and M. A. Avila. 2000. S-adenosylmethionine regulates MAT1A and MAT2A gene expression in cultured rat hepatocytes: A new role for S-adenosylmethionine in the maintenance of the differentiated status of the liver. FASEB J. 14:2511-2518.

Garrow, T. A. 1996. Purification, kinetic properties, and cDNA cloning of mammalian betaine-homocysteine methyltransferase. J. Biol. Chem. 271:22831-22838.

Goselink, R. M., J. van Baal, H. C. Widjaja, R. A. Dekker, R. L. Zom, M. J. de Veth, and A. M. van Vuuren. 2013. Effect of rumenprotected choline supplementation on liver and adipose gene expression during the transition period in dairy cattle. J. Dairy Sci. 96:1102-1116. https://doi.org/10.3168/jds.2012-5396.

Jha, P., A. Knopf, H. Koefeler, M. Mueller, C. Lackner, G. Hoefler, T. Claudel, and M. Trauner. 2014. Role of adipose tissue in methionine-choline-deficient model of non-alcoholic steatohepatitis (NASH). Biochim. Biophys. Acta 1842:959-970.

Jhee, K. H., and W. D. Kruger. 2005. The role of cystathionine betasynthase in homocysteine metabolism. Antioxid. Redox Signal. 7:813-822

Kalhan, S. C., and S. E. Marczewski. 2012. Methionine, homocysteine, one carbon metabolism and fetal growth. Rev. Endocr. Metab. Disord. 13:109-119.

Lapierre, H., G. Holtrop, A. G. Calder, J. Renaud, and G. E. Lobley 2012. Is D-methionine bioavailable to the dairy cow? J. Dairy Sci 95:353-362.

Lemley, C. O., and M. E. Wilson. 2010. Effect of cytochrome P450 and aldo-keto reductase inhibitors on progesterone inactivation in primary bovine hepatic cell cultures. J. Dairy Sci. 93:4613-4624.

Li, L., B. Chen, H. Yan, Y. Zhao, Z. Lou, J. Li, B. Fu, Z. Zhu, D. P. McManus, J. Dai, and W. Jia. 2018. Three-dimensional hepatocyte culture system for the study of Echinococcus multilocularis larval development. PLoS Negl. Trop. Dis. 12:e0006309. https:// doi.org/10.1371/journal.pntd.0006309.

Li, Z., and D. E. Vance. 2008. Phosphatidylcholine and choline homeostasis. J. Lipid Res. 49:1187-1194.

Lima, F. S., M. F. Sá Filho, L. F. Greco, and J. E. Santos. 2012. Effects of feeding rumen-protected choline on incidence of diseases and reproduction of dairy cows. Vet. J. 193:140-145. https://doi .org/10.1016/j.tvjl.2011.09.019.

Locasale, J. W. 2013. Serine, glycine and one-carbon units: cancer metabolism in full circle. Nat. Rev. Cancer 13:572-583.

Loor, J. J., M. Bionaz, and J. K. Drackley. 2013. Systems physiology in dairy cattle: Nutritional genomics and beyond. Annu. Rev. 
Anim. Biosci. 1:365-392. https://doi.org/10.1146/annurev-animal -031412-103728.

Lushchak, V. I. 2012. Glutathione homeostasis and functions: Potential targets for medical interventions. J. Amino Acids 2012:736837.

Ma, Q., J. Zhao, W. Cao, J. Liu, and S. Cui. 2015. Estradiol decreases taurine level by reducing cysteine sulfinic acid decarboxylase via the estrogen receptor-alpha in female mice liver. Am. J. Physiol. Gastrointest. Liver Physiol. 308:G277-G286.

Martinez-Chantar, M. L., M. U. Latasa, M. Varela-Rey, S. C. Lu, E. R. Garcia-Trevijano, J. M. Mato, and M. A. Avila. 2003. Lmethionine availability regulates expression of the methionine adenosyltransferase 2A gene in human hepatocarcinoma cells: Role of S-adenosylmethionine. J. Biol. Chem. 278:19885-19890.

Martinov, M. V., V. M. Vitvitsky, R. Banerjee, and F. I. Ataullakhanov. 2010. The logic of the hepatic methionine metabolic cycle. Biochim. Biophys. Acta 1804:89-96.

Osorio, J. S., P. Ji, J. K. Drackley, D. Luchini, and J. J. Loor. 2013. Supplemental Smartamine M or MetaSmart during the transition period benefits postpartal cow performance and blood neutrophil function. J. Dairy Sci. 96:6248-6263.

Osorio, J. S., P. Ji, J. K. Drackley, D. Luchini, and J. J. Loor. 2014a. Smartamine $M$ and MetaSmart supplementation during the peripartal period alter hepatic expression of gene networks in 1-carbon metabolism, inflammation, oxidative stress, and the growth hormone-insulin-like growth factor 1 axis pathways. J. Dairy Sci. 97:7451-7464.

Osorio, J. S., E. Trevisi, P. Ji, J. K. Drackley, D. Luchini, G. Bertoni, and J. J. Loor. 2014b. Biomarkers of inflammation, metabolism, and oxidative stress in blood, liver, and milk reveal a better immunometabolic status in peripartal cows supplemented with Smartamine M or MetaSmart. J. Dairy Sci. 97:7437-7450.

Park, E., S. Y. Park, C. Dobkin, and G. Schuller-Levis. 2014. Development of a novel cysteine sulfinic Acid decarboxylase knockout mouse: Dietary taurine reduces neonatal mortality. J. Amino Acids 2014:346809.

Pellanda, H., F. Namour, M. Fofou-Caillierez, A. Bressenot, J. M. Alberto, C. Chery, A. Ayav, J. P. Bronowicki, J. L. Gueant, and T. Forges. 2012. A splicing variant leads to complete loss of function of betaine-homocysteine methyltransferase (BHMT) gene in hepatocellular carcinoma. Int. J. Biochem. Cell Biol. 44:385-392.

Pinotti, L., A. Baldi, and V. Dell'Orto. 2002. Comparative mammalian choline metabolism with emphasis on the high-yielding dairy cow. Nutr. Res. Rev. 15:315-332. https://doi.org/10.1079/NRR200247.

Pooya, S., S. Blaise, M. Moreno Garcia, J. Giudicelli, J. M. Alberto, R. M. Gueant-Rodriguez, E. Jeannesson, N. Gueguen, A. Bressenot, B. Nicolas, Y. Malthiery, J. L. Daval, L. Peyrin-Biroulet, J. P. Bronowicki, and J. L. Gueant. 2012. Methyl donor deficiency impairs fatty acid oxidation through PGC-1alpha hypomethylation and decreased ER-alpha, ERR-alpha, and HNF-4alpha in the rat liver. J. Hepatol. 57:344-351.

Roche, J. R., J. K. Kay, N. C. Friggens, J. J. Loor, and D. P. Berry. 2013. Assessing and managing body condition score for the prevention of metabolic disease in dairy cows. Vet. Clin. North Am. Food Anim. Pract. 29:323-336. https://doi.org/10.1016/j.cvfa.2013.03 .003 .

Sales, J., P. Homolka, and V. Koukolova. 2010. Effect of dietary rumen-protected choline on milk production of dairy cows: A metaanalysis. J. Dairy Sci. 93:3746-3754.

Schweikl, H., J. A. Taylor, S. Kitareewan, P. Linko, D. Nagorney, and J. A. Goldstein. 1993. Expression of CYP1A1 and CYP1A2 genes in human liver. Pharmacogenetics 3:239-249.

Snoswell, A. M., and G. P. Xue. 1987. Methyl group metabolism in sheep. Comp. Biochem. Physiol. B 88:383-394.

Soto, A., and G. M. Carman. 2008. Regulation of the Saccharomyces cerevisiae CKI1-encoded choline kinase by zinc depletion. J. Biol. Chem. 283:10079-10088.
Speckmann, B., S. Schulz, F. Hiller, D. Hesse, F. Schumacher, B. Kleuser, J. Geisel, R. Obeid, T. Grune, and A. P. Kipp. 2017. Selenium increases hepatic DNA methylation and modulates one-carbon metabolism in the liver of mice. J. Nutr. Biochem. 48:112-119.

Spotorno, V. G., A. Hidalgo, M. Barbich, A. Lorenti, and O. Zabal. 2006. Culture of bovine hepatocytes: A non-perfusion technique for cell isolation. Cytotechnology 51:51-56. https://doi.org/10 .1007/s10616-006-9000-0.

Sugimoto, H., C. Banchio, and D. E. Vance. 2008. Transcriptional regulation of phosphatidylcholine biosynthesis. Prog. Lipid Res. 47:204-220.

Sun, F. F., Y. C. Cao, C. J. Cai, S. X. Li, C. Yu, and J. H. Yao. 2016 Regulation of nutritional metabolism in transition dairy cows: Energy homeostasis and health in response to post-ruminal choline and methionine. PLoS One 8:e0160659.

Tavares, C. D., K. Sharabi, J. E. Dominy, Y. Lee, M. Isasa, J. M. Orozco, M. P. Jedrychowski, T. M. Kamenecka, P. R. Griffin, S. P. Gygi, and P. Puigserver. 2016. The methionine transamination pathway controls hepatic glucose metabolism through regulation of the GCN5 acetyltransferase and the PGC-1alpha transcriptional coactivator. J. Biol. Chem. 291:10635-10645.

Wells, M. J., M. W. Hatton, B. Hewlett, T. J. Podor, W. P. Sheffield, and M. A. Blajchman. 1997. Cytokeratin 18 is expressed on the hepatocyte plasma membrane surface and interacts with thrombinantithrombin complexes. J. Biol. Chem. 272:28574-28581.

Wu, G., and D. E. Vance. 2010. Choline kinase and its function. Biochem. Cell Biol. 88:559-564

Zeisel, S. H., and J. K. Blusztajn. 1994. Choline and human nutrition. Annu. Rev. Nutr. 14:269-296.

Zenobi, M. G., R. Gardinal, J. E. Zuniga, A. L. G. Dias, C. D. Nelson, J. P. Driver, B. A. Barton, J. E. P. Santos, and C. R. Staples, 2018. Effects of supplementation with ruminally protected choline on performance of multiparous Holstein cows did not depend upon prepartum caloric intake. J. Dairy Sci. 101:1088-1110. https://doi .org/10.3168/jds.2017-13327.

Zhang, Q.. S. J. Bertics, N. D. Luchini, and H. M. White. 2016. The effect of increasing concentrations of DL-methionine and 2-hydroxy4-(methylthio) butanoic acid on hepatic genes controlling methionine regeneration and gluconeogenesis. J. Dairy Sci. 99:8451-8460.

Zhou, Z., O. Bulgari, M. Vailati-Riboni, E. Trevisi, M. A. Ballou, F. C. Cardoso, D. N. Luchini, and J. J. Loor. 2016a. Rumen-protected methionine compared with rumen-protected choline improves immunometabolic status in dairy cows during the peripartal period. J. Dairy Sci. 99:8956-8969.

Zhou, Z., T. A. Garrow, X. Dong, D. N. Luchini, and J. J. Loor. 2017. Hepatic activity and transcription of betaine-homocysteine methyltransferase, methionine synthase, and cystathionine synthase in periparturient dairy cows are altered to different extents by supply of methionine and choline. J. Nutr. 147:11-19.

Zhou, Z., M. Vailati-Riboni, D. N. Luchini, and J. J. Loor. 2016b. Methionine and choline supply during the periparturient period alter plasma amino acid and one-carbon metabolism profiles to various extents: Potential role in hepatic metabolism and antioxidant status. Nutrients 29:9.

Zhou, Z., M. Vailati-Riboni, E. Trevisi, J. K. Drackley, D. N. Luchini, and J. J. Loor. 2016c. Better postpartal performance in dairy cows supplemented with rumen-protected methionine compared with choline during the peripartal period. J. Dairy Sci. 99:8716-8732.

Zom, R. L., J. van Baal, R. M. Goselink, J. A. Bakker, M. J. de Veth, and A. M. van Vuuren. 2011. Effect of rumen-protected choline on performance, blood metabolites, and hepatic triacylglycerols of periparturient dairy cattle. J. Dairy Sci. 94:4016-4027. https://doi .org/10.3168/jds.2011-4233. 